\title{
Hubungan antara Umur dengan Bobot Non Karkas Internal dan Eksternal pada Babi Duroc Jantan di RPH Mabar Medan
}

\section{The Relation of Animal Age with Internal and External Non Carcass Weight of Male Duroc Pig at RPH Mabar Medan}

\author{
S.N. Aritonang, J. Pinem, dan T. A. Pelawi \\ Fakultas Peternakan Universitas Andalas \\ Kampus Unand Limau Manis Padang 25153 \\ E-mail : sn_aritonang@yahoo.com
}

(Diterima : 14 Oktober 2010; Disetujui: 21 Januari 2011)

\begin{abstract}
The purposed of this research was analyzed the relationship of pigs age with internal and external non carcass weight of male Duroc pigs. The experiment has been carried out on one hundred and twenty male Duroc pig, which consisted of four aged groups : A (240-270 days), B (271300 days), C (301-330 days) and D (331-360 days). The method of this research was survey method by purposive quota sampling in Mabar Slaugther House, Medan. The variables were observed of internal and external non carcass weigth (head and foot) of male Duroc pigs. The relation of animal age and variable measured is used the quadratic regression analysis. The result indicated that there are closely relation $(P<0,01)$ between animal age with internal and external non carcass weigth (head and foot) of male Duroc pig with correlation coefficient of 0.953; 0.992 and 0.950.
\end{abstract}

\section{Keywords: Duroc pig, internal non carcass, external non carcass}

\section{PENDAHULUAN}

Babi merupakan komoditi ternak yang cukup potensial karena dapat meningkatkan ekonomi bagi masyarakat perdesaan maupun pendapatan pemerintah daerah. Kontribusi ternak babi dalam usaha memenuhi kebutuhan nasional akan daging sangat nyata, baik sebagai sumber protein hewani maupun untuk di ekspor ke luar negeri. Namun kenyataannya populasi ternak babi di Indonesia masih terbatas dan belum memenuhi kebutuhan konsumsi dalam negeri. Hal ini disebabkan kondisi sosial budaya di Indonesia, yang sebagian besar masyarakat tidak mengkonsumsi daging babi.

Dilihat dari segi ekonomi, babi mampu melahirkan anak dua kali per tahun atau lima kali per dua tahun, dengan jumlah anak yang dilahirkan bisa mencapai 8 ekor/induk/kelahiran (Eusobio, 1980). Di samping itu dalam peneliharaannya ternak babi lebih efisien karena dapat memanfaatkan sisa-sisa bahan makanan, baik sisa dapur maupun sisa- sia hasil pertanian (Booth, 1995).

Babi Duroc merupakan salah satu babi yang paling terkenal, yang dikembangkan di kota New
Jersey, hasil persilangan dari dua bangsa Jersey Red dan dari New York. Babi tipe ini termasuk tipe pedaging, dengan pertambahan bobot badan yang cepat karena efisien dalam hal makanan (Sihombing, 1997). Ukuran tubuh babi Duroc adalah panjang, punggung berbentuk busur, kuat dan lebar, susunan badan padat, lemak sedikit, kepala dan leher ringan dan halus, ukuran kaki panjangnya sedang. Umumnya babi Duroc dapat mencapai berat $150 \mathrm{~kg}$ pada umur 12 bulan dan warna merah terang sampai putih kemerah-merahan adalah babi yang paling banyak disukai (Soeparno, 2005).

Karkas babi merupakan bobot seekor babi yang telah dipotong setelah dikurangi atau dipisahkan bagian kepala, paru-paru, jantung, jeroan dan ke empat kaki, sedangkan kulit, ginjal, ovarium, ekor dan leher merupakan bagian dari karkas (Anderson-Eklund, 1998). Adapun di luar karkas yang disebut non karkas menurut Eusebio (1980) dan Mc Meecan (2009) terdiri dari edible offal (non karkas yang dapat dimakan seperti jantung, hati, lidah dan saluran pencernaan, testikel, limpa paru-paru, uterus dan darah) dan inedible offal seperti gigi, tulang, kaki, rambut/bulu, kelenjar dan hasil ikutan. 
Tabel 1. Rataan bobot non karkas internal babi Duroc jantan dan hubungannya dengan umur

\begin{tabular}{ccc}
\hline $\begin{array}{c}\text { Kelompok Umur } \\
\text { (hari) }\end{array}$ & $\begin{array}{c}\text { Rataan Bobot Non Karkas } \\
\text { Internal }(\mathrm{kg}))\end{array}$ & $\begin{array}{c}\text { Koefisien Korelasi } \\
(\mathrm{r})\end{array}$ \\
\hline A & $8,00 \pm 0,42$ & 0,953 \\
B & $8,66 \pm 0,41$ & \\
C & $9,59 \pm 0,45$ & \\
D & $10,30 \pm 0,20$ & \\
\hline
\end{tabular}

Keterangan : $\mathrm{A}=240-270 ; \mathrm{B}=271-300 ; \mathrm{C}=301-330$, dan $\mathrm{D}=331-360$

Umur ternak berpengaruh terhadap bentuk tubuh ternak, di mana pada umur yang lebih tinggi menghasilkan kualitas karkas yang rendah (Ensminger, 2005). Ternak babi yang dipotong pada fase pertumbuhan dan komponen fisik karkasnya telah optimum, bobot karkas yang dihasilkan meningkat sehubungan dengan meningkatnya bobot hidup, yang juga akan berpengaruh terhadap bobot non karkas internal maupun non karkas eksternal.

\section{MATERI DAN METODE}

Penelitian ini menggunakan 120 ekor babi Duroc jantan dari berbagai umur yang dikelompokkan atas 4 kelompok umur, yaitu A (240-270 hari), B (271-300 hari), C (301-330) dan $\mathrm{D}$ (331-360 hari).

Pengelompokan berdasarkan umur bertujuan untuk mengetahui perbedaan bobot karkas dan bobot non karkas pada umur yang berbeda. Metode penelitian yang digunakan adalah metode survei dengan mengukur secara langsung peubah yang diamati, dan pengambilan sampel dilakukan secara langsung terhadap peubah yang diamati.

Pengambilan sampel dilakukan secara purposive kuota sampling di RPH Mabar, Medan. Peubah yang diukur adalah bobot non karkas internal, bobot kepala dan bobot kaki babi Duroc jantan. Pendugaan antara umur dengan peubah yang diukur digunakan analisis regresi kuadratik dengan persamaan : $\mathrm{Y}=\mathrm{a}+\mathrm{bx}+\mathrm{cx}^{2}$, di mana $\mathrm{X}$ adalah umur babi Duroc jantan, $\mathrm{Y}=$ Bobot non karkas internal dan eksternal.

\section{HASIL DAN PEMBAHASAN}

\section{Bobot non karkas internal}

Pertumbuhan kaki yang terus terjadi dengan bertambahnya umur disebabkan selama pertumbuhan terjadi peningkatan hormon yang berpengaruh terhadap pertumbuhan tulang

Bertambahnya umur telah me-ningkatkan bobot non karkas internal babi Duroc jantan, di mana pada kelompok D, yaitu umur 331-360 hari rata-rata bobot non karkas yang dicapai paling tinggi sekitar 10,30 $\pm 0,42 \mathrm{~kg}$ (Tabel 1). Peningkatan bobot non karkas internal pada periode umur tersebut disebabkan karena dengan ber-tambahnya umur akan terjadi peningkatan konsumsi pakan yang tinggi, sehingga metabolisme dan pertumbuhan semua organ dalam ternak babi pun menjadi sangat pesat. Sesuai dengan pendapat Sihombing (1997), bahwa bertambahnya umur ternak pada kurun waktu tertentu maka akan diperoleh ukuran-ukuran tubuh yang membesar.

Hasil analisis regresi menunjukkan, bahwa umur memiliki hubungan yang sangat erat $(\mathrm{P}<$ $0,01)$ dengan bobot hidup babi Duroc jantan dengan persamaan regresi $\mathrm{Y}=8,544+0,019 \mathrm{x}$ $0,06 \times 2$ dan koefisien korelasi 0,953 . Ini menunjukkan bahwa semakin bertambah umur ternak maka semakin meningkat ukuran bobot dari masing-masing organ dalam pada ternak babi seperti hati, jantung, paru-paru, limpa, lambung dan usus, yang berarti makin tinggi juga bobot non karkas internal. Sesuai dengan pendapat Sihombing (1997) bahwa bertambahnya umur ternak pada kurun waktu tertentu akan diperoleh ukuran-ukuran tubuh yang membesar. Demikian juga menurut Aberle et al. (2001) bahwa pertumbuhan bobot non karkas internal akan bertambah dengan bertambahnya umur. Seperti yang ditunjukkan dalam hasil penelitian ini, bahwa bobot non karkas internal babi Duroc jantan 95,3\% 
Tabel 2.Rataan Bobot Kaki Babi Duroc Jantan dan Hubungannya dengan Umur

\begin{tabular}{ccc}
\hline $\begin{array}{c}\text { Kelompok Umur } \\
\text { (hari) }\end{array}$ & $\begin{array}{c}\text { Rataan Bobot Non Karkas } \\
\text { Internal }(\mathrm{kg}))\end{array}$ & $\begin{array}{c}\text { Koefisien Korelasi } \\
(\mathrm{r})\end{array}$ \\
\hline $\mathrm{A}$ & $2,12 \pm 0,26$ & 0,992 \\
$\mathrm{~B}$ & $2,80 \pm 0,21$ & \\
$\mathrm{C}$ & $3,23 \pm 0,17$ & \\
$\mathrm{D}$ & $3,82 \pm 0,14$ & \\
\hline Keterangan : $\mathrm{A}=240-270 ; \mathrm{B}=271-300 ; \mathrm{C}=301-330 ; \mathrm{D}=331-360$ &
\end{tabular}

Tabel 3.Rataan Bobot Kepala Babi Duroc Jantan dan Hubungannya dengan Umur

\begin{tabular}{ccc}
\hline $\begin{array}{c}\text { Kelompok Umur } \\
\text { (hari) }\end{array}$ & $\begin{array}{c}\text { Rataan Bobot Non Karkas } \\
\text { Internal }(\mathrm{kg}))\end{array}$ & $\begin{array}{c}\text { Koefisien Korelasi } \\
(\mathrm{r})\end{array}$ \\
\hline A & $7,56 \pm 0,28$ & 0,950 \\
B & $8,25 \pm 0,24$ & \\
C & $8,74 \pm 0,24$ & \\
D & $9,25 \pm 0,32$ & \\
\hline
\end{tabular}

Keterangan : $A=240-270 ; B=271-300 ; C=301-330 ; D=331-360$

dipengaruhi oleh umur. Hasil penelitian ini sesuai dengan pendapat Muller et al. (2000) bahwa penaksiran bobot non karkas internal berdasarkan bobot masing-masing organ yang terdapat di dalamnya, merupakan hal yang sering dilakukan untuk mempertinggi nilai koefisien korelasi dalam pengukuran pada kurun waktu tertentu.

\section{Bobot Non Karkas Eksternal}

Bobot Kaki. Bertambahnya umur juga telah meningkatkan bobot kaki babi Duroc jantan, di mana pada kelompok D, yaitu umur 331-360 hari rata-rata bobot kaki yang dicapai paling tinggi sekitar 3,82 $\pm 0,14 \mathrm{~kg}$ (Tabel 2).

Menurut pendapat Frandson (1992), bahwa pada bagian kaki babi terdiri dari beberapa lapisan seperti lapisan membrane sinoval yang melekat langsung pada tulang serta otot tibialis kranialis dan otot peroneus pada tarsus dan meta tarsus, yang membungkus tulang kaki sehingga bobot badan dapat tertopang dengan sempurna.

Hasil analisis regresi menunjukkan, bahwa umur memiliki hubungan yang sangat erat $(\mathrm{P}<$ $0,01)$ dengan bobot kaki babi Duroc jantan dengan persamaan regresi $\mathrm{Y}=2,949+0,023 \mathrm{x}-0,05 \times 2$ dan koefisien korelasi 0,992 . Ini menunjukkan bahwa semakin bertambah umur ternak maka semakin meningkat ukuran dari kaki sehingga juga meningkatkan bobot kaki babi Duroc jantan. Seperti yang ditunjukkan dalam hasil penelitian

Hasil penelitian ini sesuai dengan pendapat Mourad et al. (2001) dan Ensminger (2005) bahwa pertumbuhan ternak semakin meningkat baik bagian karkas maupun bagian kaki seiring dengan waktu pemeliharaan, sehingga bobot dari karkas dan kaki juga akan mengalami peningkatan.

Bobot kaki babi Duroc jantan hasil penelitian ini yang dipotong pada umur sekitar 12 bulan (331360 hari) sekitar $3,82 \mathrm{~kg}$. Hasil ini senada dengan pernyataan Wilson (1989), bahwa rataan pemotongan pada umur 12 bulan didapat sebesar $3,9 \mathrm{Kg}$. Adapun pemotongan pada bagian kaki dilakukan setelah bagian dalam isi perut sudah dikeluarkan, dimulai dari carpus (lutut bagian depan) ke bawah dan tarsus (lutut bagian belakang) kebawah.

Bobot Kepala. Bertambahnya umur telah meningkatkan bobot kepala babi Duroc jantan, di mana pada kelompok D, yaitu umur 331-360 hari rata-rata bobot kepala yang dicapai paling tinggi sekitar $9,25 \pm 0,32 \mathrm{~kg}$.

Peningkatan bobot kepala pada periode umur tersebut disebabkan dengan bertambahnya umur. Kemudian akan terjadi pertumbuhan organ-organ 
seperti tulang kepala, otak, leher, lidah dan mata, yang meningkat disertai dengan penimbunan lemak di sekitar otot pipi sehingga bobot kepala dapat terus meningkat. Seperti yang dikemukakan oleh Frandson (1992) bahwa lapisan otot yang menyusun kepala sangat berhubungan dengan otototot lainnya di antaranya otot leher (otot sternotiroides).

Hasil analisis regresi menunjukkan, bahwa umur memiliki hubungan yang sangat erat $(\mathrm{P}<$ $0,01)$ dengan bobot kepala babi Duroc jantan dengan persamaan regresi $\mathrm{Y}=8,493+0,011 \mathrm{X}$ $0,06 \mathrm{X}^{2}$ dan koefisien korelasi 0,950 .

Ini menunjukkan bahwa semakin bertambah umur ternak maka semakin meningkat ukuran organ-organ yang menyusun kepala, sehingga juga meningkatkan bobot kepala babi Duroc jantan. Seperti yang ditunjukkan dalam hasil penelitian ini, bahwa bobot kepala babi Duroc jantan 95\% dipengaruhi oleh umur. Hasil penelitian ini sesuai dengan pendapat Soeparno (2005) bahwa pertumbuhan organ otak dan mata yang terdapat di dalam kepala akan sejalan dengan pertumbuhan dari ternak tersebut. Demikian juga menurut Frandson (1992) dan Pedone et al.(1995) bahwa pola pertumbuhan tulang pada umumnya sangat mempengaruhi pertumbuhan dari kepala, dimana komponen kepala terdiri dari 3 bagian besar yaitu tulang, mata dan otak, sisanya adalah timbunan lemak yang akan terus bertambah melewati periode postnatal.

\section{KESIMPULAN}

Umur sangat berpengaruh terhadap bobot non karkas internal dan eksternal babi

1. Duroc jantan, dengan koefisien korelasi masing-masing 0,$953 ; 0,992$. 0,950 .

2. Umur potong ternak terbaik adalah pada umur 331-360 hari.

\section{DAFTAR PUSTAKA}

Aberle E.D., J.C. Forrest., D.E. Gerrard., and E.W. Mills. 2001. Principles of Meat Science. Fourth Edition. Kendall/Hunt Publishing Company. Iowa.

Anderson-Eklund, L., L. Marklund., K. Ludstrom., C.S Haley., K. Anderson.,
I.Hansson and M. Moller. 1998. Mapping Quantitative trait loci for internal carcass and meat quality in a wild boar $\mathrm{x}$ large white intercross. Journal of Animal Science 76: 694-700.

Bee, G. 2004. Effect of early gestation feeding, birth weigth and gender of progeny on muscle fiber characteristics of pig at slaughter. Journal of Animal Science. 826836.

Booth, W.D. 1995. Wild boar farming in the United Kingdom. Journal of Mountain Ecology 3: 245-248.

Ensminger, M.E. 2005. Animal Science. The Interstate Printed and Publisher Inc. Denville, Illinois.

Eusobio, J.A. 1980. Pig Production in The Tropic. Longman Group Ltd. Essex.

Frandson, R.D. 1992. Anatomi dan Fisiologi Ternak. Edisi Keempat. Penterjemah B. Srigandhono. Gadjah Mada University Press. Yogyakarta.

Mc Meekan, C.P. 2009. The nature and variability of the carcass characters in Danish and English bacon pigs. The Journal of Agricultural Science 29: 131-141.

Mourad, M., G. Gbanamau, and L.B. Balde. 2001. Carcass characteristics of West Africa Dwarf goats under extensive system. Small Ruminant Research 42: 81-85.

Mullerm E. G. Moser., H. Bartenschlager, and H. Geldermann. 2000. Trait value of growth, carcass and meat quality in wild boar. Journal of Animal Breeding and Genetics 117: 185-202.

Pedone, P,. S. Mattioli, and L. Mattioli. 1995. Body size and growth pattern in wild boars of Ttuscany. Journal of Mountain Ecology 3: 66-68.

Sihombing, D.T.H. 1997. Ilmu Beternak Babi. Gadjah Mada University Press. Yogyakarta.

Soeparno. 2005. Ilmu dan Teknologi Daging. Gadjah Mada University Press. Yogyakarta.

Wilson, P.G. 1989. Pork Production System. United States Department of Agricultural Research Service, Houston. 